Veronica Bjurulf är doktor i pedagogiskt arbete och arbetar som lektor i teknikens didaktik vid Karlstads universitet och som postdoktor på Linköpings universitet. Hon har varit verksam som gästlärare på Stockholms universitet. Hon disputerade på en avhandling som handlar om lärares arbete med ämnet teknik i grundskolans senare år. Efter disputationen har hon fokuserat på relationen mellan teori och praktik samt transfer av kunskap mellan olika arenor i forskningsprojektet LISA (Learning In Several Arenas). Hon har också inlett arbete med learning studies i teknik. Hennes

forskningsintressen rör teknikens didaktik med fokus på kunskapsinnehåll som det kommer till uttryck i undervisning.

\title{
"You'll just have to practice until you find your own way to do it!" \\ - A narrative study about how teaching is carried out in Technical Vocational Education
}

\begin{abstract}
This article examines how different arenas contribute to students' learning in the Energy Programme and the Industry Programme at Swedish upper secondary school. The empirical data consists of semistructured interviews with three students and observations of the students, two teachers and three supervisors, focusing on how the teaching is carried out in school and workplaces, respectively. The result shows that the teaching in school and at the workplaces is carried out in different ways during students' vocational education. In school the learning is influenced by the teachers' acting as role models. This means that the teaching is normative in the sense that the teachers are demonstrating how to do. At the workplaces, the teaching differs between different supervisors and the learning is influenced by the supervisor's daily agenda and in the way the supervisor gives instructions.
\end{abstract}

\section{INTRODUCTION}

In order to maintain a strong competitive position as an industrial nation Sweden needs welleducated engineers, researchers and technicians (SOU 2010:28). Youths must be encouraged to choose technically-oriented education and career paths that will lead to employment as part of a stable workforce. Aiming to increase people's technological competence, the Swedish government launched apprenticeship training pilots in the autumn of 2008. In the experimental project students spent half their time, instead of the regular 15 weeks, in a workplace (Sveriges Riksdag, 2009). In this way students get a basic vocational education, increased job experience and advanced skills in a related career field since they have been directly instructed by a supervisor in an actual working environment (ibid. \$7). The results presented in this article comprise a study, part of the wider LISA-project (Learning In Several Arenas), focusing on one of the schools that have been part of the government's investment in the vocational training programme (SOU 2008:27). In the LISA-project students, teachers and supervisors are observed and interviewed between the years 2009-2012. 
Working life is in a state of rapid change, through development of technical equipment and materials that affect working tasks and working conditions. Taking this factor into account is an important part of the learning environment for students choosing a vocational education. Thus the three-year LISA-project focuses on learning and teaching in vocational schools and at the workplace where these changes are occurring. Within the project, several sub-studies have been conducted and reported. One part of the sub-studies consisted of interviews held with six persons within the pipe-fitting and industrial professions. The aim of the study was to understand why such technically-oriented professions would attract potential young trainees into these fields (Bjurulf, 2010). The results show different factors that influence people to start working within technically oriented trades: (1) like to work with their hands, (2) want to get an income and (3) if relatives work in the type of business. The results also illuminate three reasons for staying in the professions: (1) variation and freedom, (2) creativity and influence and (3) you get to work with your hands. In the $L I S A$-project, there are also results about transference of learning presented in an article highlighting four different kinds of transfer as preparation for future learning: (1) transfer between different arenas, (2) transfer between materials, (3) transfer between theory and practice and (4) transfer from experiences (Kilbrink \& Bjurulf, 2011). The conclusions reported in the transfer-study contribute to knowledge about the impact on students' learning from two different arenas: from classroom teaching and workplace training.

\section{Aim and Research Question}

The aim of the present study is to investigate how different arenas contribute to students' learning in the Energy Programme and the Industry Programme of upper secondary schools. This knowledge is of specific importance in a dual system where half the students' time is allocated to the workplace. The specific research question is:

What characterizes teaching in school and workplaces, respectively?

\section{INTRODUCTION TO THE RESEARCH FIELD}

Aarkrog's (2005) study shows that both theoretical training at school and practical training in the workplace are necessary since each type of associated practice offers specific opportunities for learning. And according to Tanggaard's (2007) study, while students appreciate the combination of classes in a vocational school and training in a workplace, they also somehow miss the obvious coordination of educational activities bridging between the two arenas. They experience the two as having different norms and guidelines. This is also the conclusion of Berglund's (2009) study of training for workers in the building and construction industry. Berglund's study shows that the apprenticeship system in the construction industry directs the coursework in upper secondary schools. This means that students are shaped by the conditions in the construction industry, where the more important socially-oriented aspects of teamwork and loyalty count, as opposed to getting high grades from the school. One consequence of this may be that students are more likely to develop narrowed professionalism, which is contrary to the intention of them having a broad secondary education with wider options if they decide to leave the construction vocation (ibid.). Smith, Dalton \& Dolheguy (2004) investigated students' experiences with work placement and found that students saw opportunities in getting a job that may be connected to specific skills they had learnt during their onsite training. But there are also studies pointing to the fact that employable skills are context-bound, which means that trainees learn things specific to a particular workplace and lack the underlying knowledge to transfer the skills to a different working environment (Smith \& Comyn, 2003; Snell \& Hart, 2007). In actual job placements the students were found to be only able to apply about 15-percent of the theory they had learned in school (Caravaglia, 1993; Meijers, 2008). Lindberg (2003) and Tsagalidis (2008) found that teachers expect their students to learn skills in school, that are related to vocational knowledge. Their results can be compared to Allan's (2007) critique against the focus on training for competence in vocational education and training (VET). He maintains that theoretical knowledge becomes the domain of universities 
and that vocational performance skills are developed at registered training organizations, thereby creating a gap between theory and practice. A parallel can be drawn to a study of the Swedish nine-year compulsory school, where practical and theoretical tasks were separated (Bjurulf \& Kilbrink, 2008). The conclusion of that study was that theory and practice need to be interwoven in order to help learners acquire holistic learning.

\section{Theoretical Grounding and Research Method}

The theoretical framework of this study is based on the area of the phenomenology of the lifeworld (Bengtsson, 1999). According to phenomenology of the life-world there is only one world, the human life world, but depending on people's positions, perspectives and earlier experiences they conceive phenomena in this world differently (ibid.). From phenomenological ontology it follows that empirical studies are needed in order to obtain knowledge about how teaching is carried out at schools and in the workplace, respectively. The study is ethnographic inspired, since the research was carried out by means of interviews and observations of the informants' activities at the school and in the workplaces (Kullberg, 1996).

\section{Participants and Data Collection}

This article covers interviews with three students and observations of the students and their teachers in programme- specific subjects and with their workplace supervisors (see Table 1). Due to ethical considerations, all names in the article are fictitious.

Ernst works at a company whose main functions are the installation and servicing of different heating and cooling systems, such as tanks, boilers, plumbing, and water treatment while Evert works at a company whose activities are centred on different methods of commercial heating, offering customers complete solutions for heating, cooling and electrical service. Ingemar works at an industrial company where he deals with many customers and assignments throughout numerous regions.

In March 2010, Emanuel, Elias and the rest of their classmates were informed about Section 16 of Act 2003:460 (SFS 2003:460) concerning research ethics involving people and they gave their written consent to participate in the study (Vetenskapsrådet, 2002). The same procedure was conducted with Isak and his classmates in April 2010. Emanuel and Isak were interviewed at school during May 2010 and Elias was interviewed in November 2010. The questions asked covered the students' experiences about what they learned at their school, at the company and in what ways they thought they learned best. Each of these interviews was audio taped and transcribed verbatim (see Tables $2 \mathrm{a}$ and $2 \mathrm{~b}$ ). The students were then observed and also documented by video camera at school and at the workplaces (see Tables $2 \mathrm{a}$ and $2 \mathrm{~b}$ ). The observations were necessary to be able to closely follow how the teaching was carried out in order to identify how the different arenas contributed to the students' learning. There is flexibility within the school organisation concerning the students' time of study in school and at the workplaces. There is a frequent communication between the teachers and supervisors and they adapt the teaching from the students' knowledge development and needs. For example, if one of the supervisors identifies a students' need of deepening the knowledge in a particular area, the teacher calls all the students for lessons at school. It is also the other way around, where the supervisors give the teachers a call and

Table 1 Overview of the Participants

\begin{tabular}{|l|l|l|l|}
\hline Programme & Student & Teacher & Supervisor \\
\hline Energy & Emanuel & Erik & Ernst \\
\hline Energy & Elias & Erik & Evert \\
\hline Industry & Isak & Ivan & Ingemar \\
\hline
\end{tabular}


Table 2 a Data Collection from the Energy Programme

\begin{tabular}{|l|l|l|l|}
\hline Date: & Activity: & Participants: & Time: \\
\hline $19 / 3$ & Information and written consent & Students & $30 \mathrm{~min}$ \\
\hline $19 / 3$ & Observation at school & Students, Teacher & $1 \mathrm{~h}$ \\
\hline $11 / 5$ & Interview & Student Emanuel & $20 \mathrm{~min}$ \\
\hline $12 / 5$ & Observation at school & Students, Teacher & $2 \mathrm{~h}$ \\
\hline $19 / 5$ & Observation at school & Students, Teacher & $5 \mathrm{fh} \mathrm{h}$ \\
\hline $11 / 6$ & Observation at workplace & Emanuel, Supervisor & $3 \mathrm{~h}$ \\
\hline $22 / 11$ & Interview & Student Elias & $26 \mathrm{~min}$ \\
\hline $15 / 11$ & Observation at school & Students, Teacher & $2 \mathrm{fh} \mathrm{h}$ \\
\hline $23 / 11$ & Observation at workplace & Elias, Supervisor & $5 \mathrm{~h}$ \\
\hline $30 / 11$ & Observation at workplace & Elias, Supervisor & $5 \mathrm{~h}$ \\
\hline
\end{tabular}

Table $2 b$ Data Collection from the Industry Programme

\begin{tabular}{|l|l|l|l|}
\hline Date: & Activity: & Participants: & Time: \\
\hline $19 / 4$ & Information and written consent & Students & $30 \mathrm{~min}$ \\
\hline $4 / 5$ & Interview & Student Isak & $26 \mathrm{~min}$ \\
\hline $8 / 11$ & Observation at workplace & Isak, Supervisor & $2 \mathrm{fh} \mathrm{h}$ \\
\hline $17 / 11$ & Observation at school & Students, Teacher & $2 \mathrm{fh} \mathrm{h}$ \\
\hline
\end{tabular}

inform about some specific activity that is going to take place that they find of importance for the student to take part of. Furthermore, the teachers are busy in teaching other classes during some periods. The schedule for the students' in this study therefore differs from week to week. The observations were conducted with point of departure in when the teachers told me that the teaching at school corresponded with the actual students' workplace training, i.e. when the same content were handled booth at school and at the workplace. At the Energy programme the teaching concerned bending pipes, within the course called "Heating, Ventilation and Sanitation Engineering" and at the Industry programme the teaching concerned programming, within the course called "CNC technology". The observations were also made of logistical reasons, i.e. when my agenda corresponded with the teachers' and the supervisors' agendas, and the number of observations in the different classes therefore differs.

\section{Data Analysis}

The empirical analysis is based on narrative analysis (Chase, 2005; Clandinin \& Connelly, 2000; Polkinghorne, 1995), which makes it possible to study how teaching is carried out at school and at the workplace, respectively. In this type of analysis the researcher synthesises different kinds of data into a narrative or narratives (Clandinin \& Connelly, 2000; Cortazzi, 1993; Polkinghorne, 1995). The introduction of the narrative is the plot, i.e. a summary that presents the point of the story, followed by different themes that underline the plot and gives the story meaning (ibid.). In order to give clearer meaning to the observed phenomenon, the videotapes have been watched repeatedly along with the reading of the interview transcripts several times. The aim of this analysis was to find the plot, which meant examining how the teaching was carried out at school as compared to the workplaces. It progressed by testing different themes against the plot in order to find those themes that best supported it. A narrative was thereby developed and amended through an 
iterative process. All quotes from the transcribed interviews and videotaped observation sessions are the author's translations and are marked below in italics.

\section{RESULTS}

The common narrative is introduced with the following plot:

This is the story about how different arenas contribute to students' learning in the Energy and the Industry Programmes in upper secondary schools. At school teachers explain and demonstrate different tasks before letting the students try them themselves, i.e. the teachers are role models showing the class the way to do branch-specific tasks. The students are offered to learn through practice in accordance with the teacher's demonstrations and constant response. Depending on which workplace supervisor they meet and what is on that day's agenda there are different possibilities of learning during the onsite training. They may learn by figuring things out on their own, by listening and watching, or by following instructions.

There are four themes, presented below, underlining the plot in the narrative. The first one represents teaching at school and is called "It is a foundation stone". The results from the workplace training are presented by the following three themes: "But it is you who should do the job", "Then you have something to do" and "I checked on the planning board."

\section{"It is a foundation stone"}

Student Emanuel says that he learns the basics at school while during workplace training he just learns more and more. Erik, his school teacher, introduces different tasks by showing the students what to do and how to do it. For example, he initially uses a wire to illustrate the different kinds of bends, such as an S-bend, a U-bolt bend and a $90^{\circ}$-bend. Then he shows the class how to bend actual metal pipes before letting them practice themselves:

I push the pipe into the tool and then it usually slides. So, you can lay it down [he lays the tool on a table] so it doesn't slide. And then I look at the angle. This is not that easy, but it isn't difficult either; you should never say that anything is difficult! Well, now I just have to continue bending. Now I need a wire [gets a wire]. Now, just continue bending at this angle [holds the wire above the pipe]. Does this make sense? Yes. It is also easier if you hold the tool farther away [holds the tool at arm's length at eye level].

In this way Erik shows the class how to do different tasks. Elias, another student, likes Erik's way of teaching; It fits me really well, he says. Erik explains and then you just have to practice until you find your own way how to do it. Ivan teaches in a similar way as Erik, by explaining and demonstrating to his students how things work before letting them practice for themselves:

For the function that is programmed now, all that is needed is to push a block of wood past the first sensor. This is an inductive sensor. An inductive sensor registers the metal. If we pretend that this is a mill, these wooden blocks are logs and if someone has driven nails into the logs, he will be able to sort them out. Otherwise the mill will break down. The logs passing here [points] will be dropped two-by-two thanks to a sensor that detects when something passes it and that is programmed to let them pass two at a time.

This demonstration was preceded by an introduction of automation control systems where Ivan explained binary numbers, because it is a foundation stone in how to programme and logic gates, since you build up systems with logic gates. He tells the students that, all [of] automation control is about inputs and outputs and that is what you are going to do in the lab later on, where we have a conveyor belt. During the videotaped observation session, Ivan demonstrated the conveyor belt, but told the students that they were going to programme it by logic gates later on. During this 
lesson they practiced the function of logic gates via an exercise book.

\title{
"But it is you who should do the job"
}

At Emanuel's workplace training he has to try for himself first and if he doesn't know how to do a task, or if he needs help, he may ask Ernst, his supervisor, to show him the right way. One example of this is when Ernst tells Emanuel to replace a heat pump and says you can start unscrewing it at the back, and then he leaves the room to get more tools. When Ernst returns with the tools, he comments that Emanuel had forgotten to check the dimension of the new pump before he unscrew the old one:

\author{
Emanuel: $\quad$ What should I have done? \\ Ernst: $\quad Y o u$ should have, opened [the box] and checked that it fits in. \\ Emanuel: $\quad$ But I trust you. \\ Ernst: $\quad$ But it is you who should do the job.
}

This helps Emanuel to reflect upon the importance of checking the equipment before dismantling, otherwise there is a risk that a lot of people will be affected - for example be without heating in their flats, as in this case with the heat pump. Another task Emanuel took part in during workplace training was flaxing, which means to wind a plumbing material, "flax", around joins in pieces of heating and sanitary installations in order to make them waterproof. The installation in question consisted of seven separate pieces and Ernst dismantled it before he invited Emanuel "to flax" the different pieces by hand before putting them all back together again. Afterwards Emanuel said that his first thought was to dismantle it one piece at a time, flax it and then put it back before dismantling the next piece. But when Ernst had dismantled all the pieces he got Emanuel to take the whole installation into consideration and not just focus on one single piece at a time. Ernst challenged Emanuel to think for himself.

\section{"Then you have something to do"}

Supervisors differ, says Elias, some treat you as a slave whereas others are very concerned about trying to teach you something. Most often the supervisors demonstrate and explain and then let you practice yourself and [they] go on puttering about with their own things, says Elias. After a while they check to make sure it looks okay and maybe you must adjust something. The differences between the supervisors, that Elias mentions, are also a question about the tasks that are going to be carried out. On some jobs you just have to observe, you cannot get to do as much yourself, says Elias. In relation to different tasks Evert, the supervisor, talks about safety, especially when there is electricity involved. I dare not let them [the students] in, I have to do it myself, he says. Plumbing can involve working in confined spaces, which sometimes makes it impossible to share a job with a student. That is one reason during workplace training why there are a lot of times when Evert must be performing different tasks himself, for example troubleshooting boilers that do not work and measuring for pipes. In order to give Elias something to do during such situations Evert asks him to fetch tools, carry sacks of pellets and so on; Then you have something to do he says. He also gives Elias his own tasks to carry out in addition to those he himself is occupied with. In those situations Evert and Elias sometimes joke with each other. For example, Evert asks Elias to seal a leak on a pellet container: Let's see if you can mend it with tape so it looks pretty, to which Elias replies, Must it be pretty, too?

\section{"I check on the planning board"}

Isak tells that what they read in school helps him to, come back [to the workplace] and manage to do things in a better way. Isak tells that he learns best when he is doing something; to work with my hands, he says, or when somebody shows me how to do something. This is how it works during workplace training where he is running the lathes and the milling machines. They [the supervisors] show me what to do, Isak says. Once Isak has been shown how to do it correctly he 
runs the machines on his own, but he can always ask his workmates for help if there is something he has questions about. When Isak comes to the workplace early in the morning he checks the planning board mounted on the wall in the workshop to find out which machine he shall run that day. If he needs help he can read through the instructions belonging to each machine or he just can ask someone. We are trying to give as much good instructions as possible, so you can run the machines using the same basic knowledge as for running a lathe, says Ingemar, the supervisor. At the workplace training I do the same thing as the others [employees], Isak says. Ingemar tells that Isak is not supposed be counted as a regular employee. Instead he is going to, do what he wants to and what he feels for, to practice different things at the workplace. Isak himself says that he believes that he was placed here to get experience in how it is to have a real job. Actually it's really good with this kind of practice, you learn a lot, he says. This is how I learn, but he also tells that he has not learnt all that much during his workplace training. I have learned to push the buttons that are needed and to set the dimensions on the machines, he says. Oftentimes he forgets how to do the setting up when he is going to run the same machine the next time, but you do learn what you are in to, explains Isak.

\section{Discussion}

The aim of study was to investigate how different arenas contribute to students' learning in upper secondary schools with point in departure in how the teaching is characterized in school and at the workplaces. Based on the study, the teaching in school and the workplaces is carried out in different ways during students' vocational education. How the different arenas contribute to the students' learning is expressed by Emanuel. He expressed the opinion that he learns basic knowledge at school and that the experiences from the workplace training complement this knowledge. In the classroom all the students were taught in the same way, by having their teachers show them how to do things first before they got to practice the tasks for themselves. The students are supposed to learn via a "role model" approach of what to do. The teaching is normative in the sense that the teachers are role models offering students a "tool box." The teaching at school, with the teacher as a role model, may be a result of the actual lessons that were observed since it was a limited number of lessons. Nevertheless, the observations from the two teachers show the same result. During the workplace training there was a difference in how the teaching was carried out depending on which supervisor the students' met and in the way the supervisor gave them instructions, for example written, verbally or by figuring out things alone supported by the supervisor. There are examples of supervisors, who, like the teachers, act as role models, i.e. demonstrate how to do, according to the interviews with the students. There are however a difference, since the observations at school show that the teachers are present after their demonstrations, supporting the students when they are practicing themselves, whereas the supervisors are doing something else, themselves, after their demonstrations. This indicates that the teachers are keen on the students to do as they have demonstrated in a higher degree than the supervisors. Furthermore, the "role model" approach did not show up during the observations at the workplaces. The results show that the supervisor's daily agenda influence how the teaching is carried out. Some days they have tasks to do where it is unsuitable for the students to be an active part of the work mostly due to safety considerations.

The student Isak stated that school helps him to conduct the workplace training in a better way. These results supports Aarkrog's (2005) study saying that teaching in both school and at the workplaces are necessary since they offer specific opportunities for learning. In this study, the student Emanuel says that he learns the basics at school and then he learns more and more during the workplace training. This result is an example of that students use their knowledge from school in their workplace situation. But this study does not investigate in what degree the students use their knowledge from school - or vice versa, which is investigated in other studies where the students' only were able to apply about 15-percent of what they had learned in school at the workplaces (Caravaglia, 1993; Meijers, 2008). 
To date, unlike the students in Tanggaard's (2007) research, there have been no tendencies seen in this study of students experiencing the two teaching arenas as having different norms and guidelines. The result is interesting; could it be a consequence of a well-established and functioning contact between teacher and supervisors? However, the result in this particular study indicates a similar result as Berglund's (2009) study that socially-oriented aspects of teamwork and loyalty count as important at the workplace training. For example says Isak that his workplace training aimed to teach him about being a worker, i.e. to get experience in how it is to have a real job rather than to develop knowledge specific to the tasks specific to the profession. This result echoes Berglund's study where others skills than good performance at school are highly important from an employability perspective. According to earlier research, employable job skills are context-bound and can only be fully appreciated in the workplace where the consequences of such skills can be seen (Smith \& Comyn, 2003; Snell \& Hart, 2007). This study implies that to fully develop such abilities there is a need for basic knowledge obtained from vocational schools. This basic knowledge may constitute the foundation for students to be able to apply their skills in a different arena - even if the meaning of what this basic knowledge is needs to be investigated further.

\section{CONCLUSION}

The conclusion of the study is that teaching is carried out in different ways in school and at the workplaces which gives the students possibilities to fill their personal "boxes" with the tools that fits themselves in their future professions. Both arenas contribute to the students' learning of the professions they have chosen to study for, but it is up to the individual student to use the different arenas possibilities and become equipped to adapt and use the tools in their own way, or, as Elias says: You just have to practice until you find your own way to do it!

\section{REFERENCES}

Aarkrog, V. (2005). Learning in the workplace and the significance of school-based education: A study of learning in a Danish vocational education and training program. International Journal of Lifelong Education, 24(2), 137-147.

Allan, J. (2007). Snapshot of a generation: Bridging the theory-practice divide with project-based learning. Australian Journal of Adult Learning, 47(1), 78-93.

Bengtsson, J. (1999). Med livsvärlden som grund: Bidrag till utvecklandet av en livsvärldsfenomenologisk ansats $i$ pedagogisk forskning. Lund: Studentlitteratur.

Berglund, I. (2009). Byggarbetsplatsen som skola - eller skolan som byggarbetsplats?. Stockholm: Institutionen för didaktik och pedagogiskt arbete, Stockholms universitet.

Bjurulf, V. (2010). Reasons for choosing a technically oriented education: An interview study within the fields of pipefitting and industry. International Journal of Technology and Design Education, (DOI: 10.1007/s10798-010-9141-5)

Bjurulf, V., \& Kilbrink, N. (2008). The importance of interweaving theoretical and practical tasks in technology education. In H. Middleton, \& M. Pavlova (Eds.), Exploring technology education: Solutions to issues in a globalised world (pp. 27-34) Griffith University.

Caravaglia, P. L. (1993). How to ensure transfer of training. Training and Development, 47(10), 63-68.

Chase, S. E. (2005). Narrative inquiry. In N. K. Denzin, \& Y. S. Lincoln (Eds.), The SAGE handbook of qualitative research (3rd ed., ). Thousand Oaks, Calif: Sage Publications, Inc.

Clandinin, D. J., \& Connelly, F. M. (2000). Narrative inquiry: Experience and story in qualitative research. San Fransisco, CA: Jossey-Bass Publishers.

Cortazzi, M. (1993). Narrative analysis. London: Falmer Press.

Kilbrink, N., \& Bjurulf, V. (2011). Different kinds of transfer in technical vocational education. In K. Stables, C. Benson \& M. de Vries (Eds.), Perspectives on learning in design \& technology education (pp. 231-235) London: Goldsmiths University. 
Kullberg, B. (1996). Etnografi i klassrummet Lund: Studentlitteratur.

Lindberg, V. (2003). Vocational knowing and the content in vocational education. International Journal of Training Research, Volume 1 (Number 2), pp 40-61.

Meijers, F. (2008). Mentoring in Dutch vocational education: An unfulfilled promise. British Journal of Guidance \& Counselling, 36(3), 237-256.

Polkinghorne, D. E. (1995). Narrative configuration in qualitative analysis. In J. A. Hatch, \& R. Wisniewski (Eds.), Life history and narrative (pp. 5-23). London: Falmer Press.

SFS 2003:460. Lag om etikprözning av forskning som avser människor. Stockholm: Riksdagen.

Smith, E., \& Comyn, P. (2003). The development of employability skills in novice workers. NCVER: Australia.

Smith, P. J., Dalton, J., \& Dolheguy, R. (2004). Student experiences of work placement in schoolbased vocational programs. Education and Training, 46(5), 262-268.

Snell, D., \& Hart, A. (2007). Vocational training in Australia: Is there a link between attrition and quality? Education and Training, 49(6), 500-512.

SOU 2008:27. (2008). Framtidsvägen - en reformerad gymnasieskola No. 2008:27). Stockholm: Fritzes.

SOU 2010:28. Vändpunkt Sverige: Ett ökat intresse för matematik, naturvetenskap, teknik och IKT Stockholm: Elanders Sverige AB.

Sveriges Riksdag. (2009). Förordning (2007:1349) om försöksverksamheten med gymnasial lärlingsutbildning. Retrieved 9.juli 2009 http://www.riksdagen.se/webbnav/index. aspx? nid=3911\&bet=2007:1349

Tanggaard, L. (2007). Learning at trade vocational school and learning at work: Boundary crossing in apprentices'everyday life. Journal of Education and Work, 20(5), 453-466.

Tsagalidis, H. (2008). Därför fick jag bara godkänt...bedömning i karaktärsämnen på HR-programt. (Doktorsavhandlingar från Pedagogiska institutionen, nr. 149). Stockholm: Stockholms universitet.

Vetenskapsrådet. (2002). Forskningsetiska principer inom humanistisk-samhällsvetenskaplig forskning. Stockholm: Vetenskapsrådet. 